\title{
Looking back at the 2008-crisis lesson to help Vietnam's stock market hold its attraction to investors
}

\author{
Minh-Hoang Nguyen \\ Centre for Interdisciplinary Social Research \\ Phenikaa University \\ Yen Nghia, Ha Dong, Hanoi 100803, Vietnam
}

September 19, 2021

\begin{abstract}
$* * * * *$
Since February 2020, the stock markets around the globe have plunged as the Covid-19 pandemic spread globally. Vietnam's stock market is not an exception; the VN-Index dropped rapidly from nearly 900 points in February to the bottom of approximately 650 points in March 2020. However, the VN-Index steadily recovered and even marked a new record beyond the 1400 -point milestone on June $28^{\text {th }} 2021$ [1].

Despite the severe socio-economic impacts caused by the fourth wave of the Covid-19 pandemic since July 2021, the VN-Index still not fell below 1300 points, and it is currently rising back to the 1400-point milestone again. This hints at a high expectation of investors towards the future of the Vietnamese economy. Investors' expectations, nevertheless, can diminish and drive them to leave in the future if Vietnam's macroeconomy becomes less stable and the pandemic cannot be contained.

To keep the macroeconomy stable, looking back at the lesson in the 2008 crisis is necessary [2]. The high inflation rate $(23.115 \%)$ could significantly devalue the assets' real values, including stocks with dividends. At the end of 2008, the VN-index had dropped by $66.9 \%$ since the end of 2007 [3]. Therefore, controlling inflation at a low rate is critical to stabilize the macroeconomy and eventually keep the stock market hold its attraction to both domestic and foreign investors.
\end{abstract}

Implementing new economic plans, fiscal and monetary policies to help the economy recover in the new "normal stage" is important, but limiting the rise of inflation must not be neglected.

\section{References}

[1] Chí Kiên. (2021). Vượt mốc 1,400, VN-Index lập kỷ lục mới. VietStock. Retrived from: https://vietstock.vn/2021/06/vuot-moc-1400-vn-index-lap-ky-luc-moi-830869708.htm 
[2] Chính PM, Hoàng VQ. (2021). Kinh tế Việt Nam: Thăng trầm và đột phá. Nxb Chính trị Quốc gia, Hà Nội.

[3] Thùy Vân. (2008). 10 sự kiện chứng khoán nổi bật năm 2008. Retrived from: https://nhandan.vn/tin-tuc-kinh-te/10-sự-kiện-chứng-khoán-nổi-bật-năm-2008$\underline{516425}$ 